\title{
ANALISIS KINERJA BELANJA DAERAH DI KABUPATEN SAROLANGUN
}

\author{
Irhamna Andriani \\ Program Studi Keuangan Daerah FEB Universitas Jambi \\ sukmabakti2020@gmail.com
}

\begin{abstract}
Abstrak
Tujuan penelitian ini adalah untuk Menganalisis perkembangan belanja daerah Kabupaten Sarolangun dan Menganalisis bagaimana kinerja belanja daerah Kabupaten Sarolangun. Metode yang digunakan yaitu analisis deskriptif dan kuantitatif dengan menggunakan analisis perkembangan belanja daerah, analisis pertumbuhan belanja, analisis keserasian belanja, analisis efesiensi belanja. Hasil penelitian menunjukkan bahwa perkembangan belanja daerah Kabupaten Sarolangun selama tahun 2006-2012 mengalami perkembangan rata-rata 20,67\%. Untuk kinerja belanja daerah dari sisi keserasian dikatakan baik dalam mengalokasikan belanja daerah karena alokasi belanja operasional lebih besar daripada belanja modal. Sedangkan tingkat rata-rata efesiensi belanja Pemerintah Kabupaten Sarolangun selama tahun 2006-2012 sebesar 86,64\% yang tergolong efesien
\end{abstract}

Kata Kunci : kinerja, belanja daerah, kabupaten

\begin{abstract}
The purpose of this study is to analyze the development of regional spending in Sarolangun Regency and to analyze how the performance of regional spending in Sarolangun Regency. The method used is descriptive and quantitative analysis using regional expenditure development analysis, expenditure growth analysis, spending harmony analysis, spending efficiency analysis. The results showed that the development of regional spending in Sarolangun Regency during 2006 - 2012 experienced an average development of $20.67 \%$. In terms of harmony, regional expenditure performance is said to be good in allocating regional expenditure because the allocation of operational expenditure is greater than capital expenditure. Meanwhile, the average level of government spending efficiency in Sarolangun Regency during 2006 - 2012 was $86.64 \%$ which is classified as efficient.
\end{abstract}

Keywords: performance, regional expenditure, district

\section{PENDAhUluAN}

Pada dasarnya pemerintah mempunyai peran sebagai aktor sekaligus fasilitator dalam menggerakkan roda perekonomian. Peran tersebut dilakukan baik oleh pemerintah pusat selaku pengawal perekonomian nasional, maupun pemerintah daerah dalam konteks perekonomian lokal. Peran sebagai aktor terutama akan dilakukan oleh pemerintah melalui belanja-belanja yang mampu secara langsung mendorong pergerakan roda perekonomian, baik di tingkat nasional maupun lokal, misalnya melalui pembangunan infrastruktur atau pembangunan sarana layanan publik yang vital.

Sementara peran sebagai fasilitator akan lebih banyak ditunjukkan melalui kebijakan- kebijakan yang kondusif terhadap pembangunan ekonomi, baik melalui kebijakan fiskal maupun kebijakan non fiskal. Dalam konteks pembangunan di daerah, maka kedua peran tersebut di atas akan nampak dalam kebijakan fiskal daerah. Instrumen kebijakan fiskal yang digunakan oleh pemerintah daerah dalam rangka melakukan 
pelayanan publik dan mendorong pertumbuhan ekonomi akan tercermin dalam Anggaran Pendapatan dan Belanja Daerah (APBD). APBD yang direncanakan setiap tahun dengan mendapatkan persetujuan dari Dewan Perwakilan Rakyat Daerah (DPRD) pada dasarnya menunjukkan sumber-sumber pendapatan daerah, berapa besar alokasi belanja untuk melaksanakan program/kegiatan dan sumber-sumber pendapatan, serta pembiayaan yang muncul bila terjadi surplus atau defisit.

Sumber pendapatan daerah tentunya masih bersandar pada penerimaan pajak dan retribusi daerah ditambah dengan dana transfer dari pemerintah pusat serta bisa juga berasal dari lain-lain pendapatan daerah yang sah. Deskripsi dan Analisis APBD Perwujudan pelayanan publik di daerah tentunya berkorelasi erat dengan kebijakan belanja daerah.

Belanja daerah merupakan seluruh pengeluaran yang dilakukan oleh pemerintah daerah untuk mendanai seluruh program/kegiatan yang berdampak langsung maupun tidak langsung terhadap pelayanan publik di daerah. Dalam hal penganggaran tentunya bisa terjadi selisih antara pendapatan dan belanja daerah, penyebabnya bisa sangat beragam, akan tetapi surplus atau defisit daerah yang timbul tersebut tentunya perlu disikapi oleh daerah dengan kebijakan pembiayaan daerah. Bila terjadi surplus atau SILPA maka daerah bisa mengoptimalisasi dana tersebut untuk mendanai belanja kegiatan yang telah direncanakan, akan tetapi bila terjadi defisit maka daerah perlu mencari alternatif pembiayaan lain yang bisa berupa pinjaman daerah atau melakukan penghematan anggaran dengan melakukan penyisiran kegiatan yang tidak perlu dilaksanakan atau ditunda pelaksanaannya.

Kabupaten Sarolangun salah satu daerah otonom di Provinsi Jambi merupakan daerah yang belanja daerahnya selalu mengalami peningkatan setiap tahunnya pada tahun 2006,2009 2012 peningkatan belanja daerah seiring dengan peningkatan kebutuhan pembangunan daerah berbagai aspek yang dapat dilihat dari kinerja belanja daerah di antaranya adalah: varians belanja, pertumbuhan belanja, keserasian belanja, rasio belanja, rasio terhadap PDRB.

Pada tahun 2008 secara keseluruhan realisasi belanja tidak langsung dalam tahun anggaran 2008 di Kabupaten Sarolangun sebesar 86,92\% dari Rp.170.437.337.018 atau sebanyak Rp.148.145.779.084. dengan demikian terdapat kelebihan anggaran sebanyak Rp.22.291.557.937. Belanja pegawai terealisasi sebesar $87,45 \%$ atau $85,35 \%$ dari total belanja tidak langsung, untuk bantuan sosial terealisasi sebesar $71,18 \%$ atau $3,91 \%$ dari belanja tidak langsung.

Dalam tahun anngaran 2009 di Kabupaten Sarolangun secara keseluruhan belanja tidak langsung sebesar 84,74\% dari Rp.207.004.346.373,00 atau sebanyak Rp.175.423.291.246,00 dengan demikian terdapat kelebihan anggaran sebanyak Rp.31.581.055.127,00 Belanja pegawai terealisasi sebesar 84,20\% dari belanja tidak langsung. Belanja bantuan sosial terealisasi sebesar Rp.8.811.928.000,00 atau 5,02\% dari belanja tidak langsung.

\section{Tujuan Penelitian}

1. Untuk menganalisis bagaimana perkembangan Belanja Daerah Kabupaten Sarolangun tahun 2006- 2012

2. Untuk menganalisis bagaimana kinerja Belanja Daerah Kabupaten Sarolangun tahun 2006-2012 


\section{METODE PENELITIAN}

\section{Jenis Data}

Jenis data yang digunakan dalam penelitian ini adalah data sekunder yang terdiri dari Data jumlah pembiayaan infrastruktur. Data sekunder merupakan data yang diambil dari pihak lain atau merupakan data yang sudah diolah oleh pihak ketiga, secara berkala (time series) untuk melihat perkembangan objek penelitian selama periode tertentu (2006-2012).

\section{Sumber Data}

Dalam penelitian ini data bersumber dari Dinas Pendapatan Pengelolaan Keuangan dan Aset Daerah (DPPKAD) Kabupaten Sarolangun, BAPPEDA, Biro Pusat Statistik Kabupaten Sarolangun.

\section{Analisis Data}

Alat analisis yang digunakan dalam penelitian ini yaitu menggunakan :

1. Rumus untuk mengetahui perkembangan belanja daerah di Kabupaten Sarolangun

$$
P B D=\frac{B D_{t}-B D_{t-1}}{B D_{t-1}} \times 100 \%
$$

2. Rumus untuk mengetahui Kinerja Belanja Daerah Kabupaten Sarolangun

1. Analisis pertumbuhan belanja daerah

$$
\text { pertumbuhan belanja Tht }=\frac{R B \text { Tht }-R B \text { Tht_1 }}{\text { realisasi belanjaTht_1 }} X 100 \%
$$

2. Analisis keserasian belanja daerah

$$
\text { Rasio blnj operasional trhdp total blnj }=\frac{\text { Realisasi blnja operasional }}{\text { Realisasi blanja daerah }} \times 100 \%
$$

$$
\text { Rasio blnj modal trhdp total blnj }=\frac{\text { Realisasi blnja modal }}{\text { Realisasi belanja daerah }} \times 100 \%
$$

3. Rasio efesiensi belanja daerah

$$
\text { Rasio ef esiensi belanja }=\frac{\text { Realisasi belanja }}{\text { Anggaran belanja }} \times 100 \%
$$

\section{HASIL DAN PEMBAHASAN}

\section{Perkembangan Belanja Daerah Kabupaten Sarolangun}

Penerimaan pembiayaan belanja daerah Kabupaten Sarolangun dari tahun 2006 2012 memiliki rata - rata perkembangan yang positif yaitu sebesar 20,67\%. Pada tahun 2006 mengalami peningkatan sebesar 21,01\% atau menjadi sebesar Rp.256.246.705.519. Pada tahun 2007 pembiayaan belanja daerah mengalami perkembangan yang negatif dan yang paling rendah yaitu sebesar 52,31\% atau dari sebesar Rp. 390.293.934.693,50. Tahun 2008 mengalami peningkatan yaitu sebesar 29,32\% atau menjadi sebesar Rp. 504.753.153.555 dibanding pada tahun sebelumnya yaitu pada tahun 2007 .

Selanjutnya tahun 2009 perkembangan belanja daerah adalah yang tertinggi dengan peningkatan menjadi sebesar Rp. 556.199.342.527 atau berkembangnya sebesar 10,19\% dibanding pada tahun 2008. Tahun 2010 mengalami perkembangan yang negatif dan yang paling rendah sebesar $-11,89 \%$ atau menjadi sebesar Rp. 490.048.757.918 
dibanding pada tahun sebelumnya yaitu pada tahun 2009. Pada tahun 2011 pembiayaan belanja daerah mengalami peningkatan sebesar $29,57 \%$ atau menjadi sebesar Rp. 634.977.459.085 dibanding pada tahun sebelumnya yaitu pada tahun 2010.

Sedangkan tahun 2012 pembiayaan belanja daerah mengalami perkembangan yang negatif yaitu sebesar 14,23\% atau menjadi sebesar Rp. 725.384.968.323 dibandingkan pada tahun 2011. Perkembangan dari tahun 2006 - 2012 hanya ada satu perkembangan yang negatif yaitu pada tahun 2010, sedangkan pada tahun 2006, 2007, 2008, 2009, 2011, 2012 perkembangannya positif. Berdasarkan perhitungan tersebut dapat dilihat bahwa perkembangan belanja daerah di Kabupaten Sarolangun belum baik. Untuk lebih jelas dapat dilihat pada tabel 1 .

Tabel 1. Perkembangan Belanja Daerah Kabupaten Sarolangun

Tahun 2006-2012

\begin{tabular}{|c|c|c|}
\hline Tahun & Belanja Daerah & Perkembangan ( \% ) \\
\hline 2006 & $256.246 .705 .519,00$ & 21,01 \\
\hline 2007 & $390.293 .934 .693,50$ & 52,31 \\
\hline 2008 & $504.753 .153 .555,00$ & 29,32 \\
\hline 2009 & 556.199 .342 .527 & 10,19 \\
\hline 2010 & 490.048 .757 .918 & $(11,89)$ \\
\hline 2011 & 634.977 .459 .085 & 29,57 \\
\hline 2012 & 725.384 .968 .323 & 14,23 \\
\hline \multicolumn{2}{|c|}{ Rata - rata } & $\mathbf{2 0 , 6 7}$ \\
\hline
\end{tabular}

Sumber : DPPKAD Kabupaten Sarolangun ( data diolah )

\section{Kinerja Belanja Daerah Kabupaten Sarolangun}

1. Analisis Pertumbuhan Belanja Daerah

Pertumbuhan belanja daerah dilakukan untuk mengetahui dan mengevaluasi perkembangan kinerja belanja daerah serta kecendrungan baik berupa kenaikan atau penurunan kinerja selama kurun waktu tertentu. Untuk mengukur pertumbuhan belanja daerah dengan cara realisasi belanja daerah tahun tertentu dikurangi realisasi belanja daerah tahun sebelumnya dan dibandingkan dengan realisasi belanja daerah tahun sebelumnya agar diketahui seberapa besar pertumbuhannya. Dengan diketahuinya tingkat pertumbuhan sumber pendapatan dan pengeluaran suatu daerah selama beberapa periode tahun anggaran. Maka data tersebut dapat digunakan untuk mengetahui bagianbagian atau potensi-potensi mana yang perlu mendapat perhatian khusus bagi Pemerintah Daerah. Sehingga Pemerintah Daerah tersebut dapat memperbaiki kinerjanya menjadi lebih baik untuk kedepannya. Untuk lebih jelas dapat dilihat pada tabel 2.

Tabel 2. Pertumbuhan Belanja Daerah

Tahun 2006 - 2012

\begin{tabular}{|c|c|c|}
\hline Tahun & Realisasi Belanja Daerah & Tingkat Pertumbuhan \\
\hline 2006 & 256.246 .705 .519 & 21,01 \\
\hline 2007 & $390.293 .934 .693,50$ & 52,31 \\
\hline 2008 & 504.753 .153 .555 & 29,32 \\
\hline 2009 & 556.199 .342 .527 & 10,19 \\
\hline 2010 & 490.048 .757 .918 & $(11,89)$ \\
\hline 2011 & 634.977 .459 .085 & 29,57 \\
\hline 2012 & 725.384 .968 .323 & 14,23 \\
\hline \multicolumn{2}{|r|}{ Rata-rata } & 20,67 \\
\hline
\end{tabular}

Sumber : DPPKAD Kabupaten Sarolangun Tahun 2012 ( data diolah ) 
Pertumbuhan belanja Kabupaten Sarolangun menunjukkan pertumbuhan yang positif dengan rata-rata sebesar $20,67 \%$ meskipun untuk tahun 2010 pertumbuhannya negatif yaitu sebesar $-11,89 \%$. Kecenderungan pertumbuhan belanja Kabupaten Sarolangun fluktuatif terlihat dari tahun 2006 - 2012 pertumbuhan berturut - turut yaitu sebesar $21,01 \%, 52,31 \%, 29,32 \%, 10,19 \%,-11,89 \%, 29,57 \%, 14,23 \%$.

\section{Analisis Keserasian Belanja Daerah}

\subsection{Analisis Keserasian Belanja Operasi Terhadap Total Belanja Daerah}

Analisis belanja operasi terhadap total belanja merupakan perbandingan antara total belanja operasi dengan total belanja daerah. Rasio ini menginformasikan kepada pembaca laporan mengenai porsi belanja daerah yang dialokasikan untuk belanja operasi. Belanja operasi merupakan belanja yang manfaatnya habis dikonsumsi dalam satu tahun anggaran, sehingga belanja operasi ini sifatnya jangka pendek dan dalam hal tertentu sifatnya rutin dan berulang (recurrent). Pada umunya proporsi belanja operasi mendominasi total belanja daerah, yaitu antara 60-90 persen. Pemerintah daerah dengan tingkat pendapatan tinggi cenderung memiliki porsi belanja operasi yang lebih tinggi dibandingkan pemerintah daerah yang tingkat pendapatannya rendah. Untuk lebih jelas dapat dilihat pada tabel 3 .

Tabel 3. Rasio Keserasian Belanja Operasi Terhadap Total Belanja Daerah Tahun 2006 -2012

\begin{tabular}{|c|c|c|c|c|}
\hline Tahun & $\begin{array}{c}\text { Realisasi Belanja } \\
\text { Operasi }\end{array}$ & $\begin{array}{l}\text { Total Belanja } \\
\text { Daerah }\end{array}$ & Proporsi & Keterangan \\
\hline 2006 & 32.565 .671 .616 & 256.246 .705 .519 & 12,70 & Tidak serasi \\
\hline 2007 & $240.685 .330 .971,50$ & $390.293 .934 .693,50$ & 61,66 & Serasi \\
\hline 2008 & 339.242 .147 .505 & 504.753 .153 .555 & 67,20 & Serasi \\
\hline 2009 & 372.116 .306 .223 & 556.199 .342 .527 & 66,90 & Serasi \\
\hline 2010 & 373.120 .049 .406 & 490.048 .757 .918 & 76,13 & Serasi \\
\hline 2011 & 448.053 .261 .274 & 634.977 .459 .085 & 70,56 & Serasi \\
\hline 2012 & 505.578 .240 .245 & 725.384 .968 .323 & 69,69 & Serasi \\
\hline \multicolumn{3}{|c|}{ Rata-rata } & 60,69 & Serasi \\
\hline
\end{tabular}

Sumber : DPPKAD Kabupaten Sarolangun ( data diolah ).

Dilihat dari perhitungan persentase keserasian belanja operasi terhadap total belanja daerah pada tabel 5.3 diatas menunjukkan bahwa selama periode tahun 20062012 nilai rata-rata belanja operasi terhadap total belanja daerah sebesar 60,69\%. Nilai tertinggi terjadi pada tahun 2010 sebesar 76,13\%. Sedangkan nilai terendah terjadi pada tahun 2006 sebesar 12,70\%. Hal ini menunjukkan bahwa Pemerintah Kabupaten Sarolangun dalam mengelola belanja daerah menurut kriteria keserasian belanja dikatakan serasi dalam mengalokasikan dananya.

\subsection{Analisis Keserasian Belanja Modal Terhadap Total Belanja Daerah}

Analisis belanja modal terhadap total belanja merupakan perbandingan antara total realisasi belanja belanja modal dengan total belanja daerah. Berdasarkan rasio ini, pembaca laporan dapat mengetahui porsi belanja daerah yang dialokasikan untuk investasi dalam bentuk belanja modal pada tahun anggaran bersangkutan. Berbeda 
dengan belanja operasi yang bersifat jangka pendek dan rutin, pengeluaran belanja modal yang dilakukan saat ini akan memberikan manfaat jangka menengah dan panjang. Selain itu belanja modal juga tidak bersifat rutin. Belanja modal ini akan mempengaruhi neraca pemerintah daerah, yaitu menambah aset daerah. Kebalikan dengan belanja operasi, pemerintah daerah dengan tingkat pendapatan daerah rendah pada umumnya justru memiliki proporsi tingkat belanja modal yang lebih tinggi dibandingkan pemerintah daerah dengan pendapatan tinggi. Hal ini disebabkan pemerintah daerah dengan pendapatan rendah berorientasi untuk giat melakukan belanja modal sebagai bagian dari investasi modal jangka panjang, sedangkan pemerintah daerah yang pendapatannya tinggi biasanya talah memiliki aset modal yang mencukupi. Pada umumnya proporsi belanja modal terhadap total belanja daerah adalah antara 5-20 persen. Untuk lebih jelas lihat tabel 4.

Tabel 4. Rasio Keserasian Belanja Modal Terhadap Total Belanja Daerah Tahun 2006 - 2012

\begin{tabular}{|c|c|c|c|c|}
\hline Tahun & $\begin{array}{c}\text { Realisasi Blnja } \\
\text { Modal }\end{array}$ & $\begin{array}{c}\text { Total Belanja } \\
\text { Daerah }\end{array}$ & Proporsi & Keterangan \\
\hline 2006 & 78.491 .085 .199 & 256.246 .705 .519 & 30,63 & Kurang serasi \\
\hline 2007 & $149.446 .370 .637,00$ & $390.293 .934 .693,50$ & 38,29 & Kurang serasi \\
\hline 2008 & 165.025 .771 .050 & 504.753 .153 .555 & 32,69 & Kurang serasi \\
\hline 2009 & 183.832 .976 .304 & 556.199 .342 .527 & 33,05 & Kurang serasi \\
\hline 2010 & 115.678 .758 .512 & 490.048 .757 .918 & 23,60 & Kurang serasi \\
\hline 2011 & 185.875 .313 .011 & 634.977 .459 .085 & 29,27 & Kurang serasi \\
\hline 2012 & 219.506 .728 .078 & 725.384 .968 .323 & 30,26 & Kurang serasi \\
\hline \multicolumn{5}{|c|}{ Rata-rata } \\
\hline
\end{tabular}

Sumber : DPPKAD Kabupaten Sarolangun ( data diolah )

Keserasian belanja daerah terhadap total belanja daerah tersebut dapat ditentukan dengan membagi realisasi belanja modal dengan total belanja daerah. Hasil perhitungan dari keserasian belanja modal terhadap total belanja daerah di Kabupaten Sarolangun selama tahun 2006-2012 memiliki rata-rata sebesar 31,11\%. Nilai tertinggi tepada terjadi pada tahun anggaran 2007 yaitu sebesar 38,29\%, sedangkan nilai terendah terjadi pada tahun 2010 yaitu sebesar 23,60\%. Alokasi dana yang terbanyak digunakan yaitu tahun 2007 yang terealisasi untuk belanja modal Pemerintah Daerah Kabupaten Sarolangun sebesar 38,29\%. Bedasarkan kriteria keserasian belanja daerah bila dilihat dari rata-ra keserasian belanja daerah tahun 2006-2012 dikatakan kurang serasi untuk kategori belanja modal.

Berdasarkan kedua tabel keserasian belanja operasi terhadap total belanja daerah dan tabel keserasian belanja modal terhadap total belanja daerah dari perhitungan diatas dapat diketahui bahwa dari ketujuh tahun tersebut, Pemerintah Kabupaten Sarolangun sangat memperioritaskan belanjanya untuk belanja operasi. Dengan proporsi masingmasing adalah $12,70 \%, 61,66 \%, 67,20 \%, 66,90 \%, 76,13 \%, 70,56 \%, 69,69 \%$ dengan rata- rata sebesar $60,69 \%$. Sedangkan untuk belanja modal atau belanja langsung hanya sebesar masing-masing 30,63\%, 38,29\%, 32,69\%, 33,05\%, 23,60\%, 29,27\%, 30,26\% dengan rata- rata sebesar $31,11 \%$. Pemerintah Kabupaten Sarolangun lebih memperioritaskan untuk belanja operasi, sedangkan untuk belanja modal masih sangat 
kecil sekali. Hal tersebut sangatlah tidak baik, dikarenakan harusnya pemerintah Kabupaten Sarolangun lebih mementingkan untuk belanja modal atau setidaknya seimbang antara kedua belanja tersebut.

\section{Analisis Efesiensi Belanja Daerah}

Rasio efisiensi belanja ini digunakan untuk mengukur tingkat penghematan anggaran yang dilakukan pemerintah. Angka yang dihasilkan dari rasio efisiensi ini tidak bersifat absolute, tetapi relative. Artinya tidak ada standar baku yang dianggap baik untuk rasio ini. Kita hanya dapat mengatakan bahwa tahun ini belanja pemerintah daerah lebih efisien dibanding tahun sebelumnya. Pemerintah daerah di nilai telah melakukan efisiensi anggaran jika rasio efisiensinya kurang dari $100 \%$. Sebaliknya jika melebihi $100 \%$ maka mengindikasikan terjadinya pemborosan anggaran.

Tabel 5. Rasio Efesiensi Belanja Daerah Tahun 2006-2012

\begin{tabular}{|c|c|c|c|c|}
\hline Tahun & $\begin{array}{c}\text { Realisasi Belanja } \\
\text { Daerah }\end{array}$ & $\begin{array}{c}\text { Anggaran Belanja } \\
\text { Daerah }\end{array}$ & Proporsi & Keterangan \\
\hline 2006 & 256.246 .705 .519 & 346.834 .299 .800 & 73,88 & Efesiensi \\
\hline 2007 & $390.293 .934 .693,50$ & $499.268 .348 .517,26$ & 78,17 & Efesiensi \\
\hline 2008 & 504.753 .153 .555 & 590.181 .497 .844 & 85,53 & Efesiensi \\
\hline 2009 & 556.199 .342 .527 & 586.079 .709 .973 & 94,90 & Efesiensi \\
\hline 2010 & 490.048 .757 .918 & 511.649 .691 .846 & 95,78 & Efesiensi \\
\hline 2011 & $634.977 .459 .085,00$ & $709.927 .813 .915,17$ & 89,44 & Efesiensi \\
\hline 2012 & 725.384 .968 .323 & 816.611 .263 .104 & 88,83 & Efesiensi \\
\hline \multicolumn{5}{|c|}{ Rata-rata } \\
\hline
\end{tabular}

Sumber : DPPKAD Kabupaten Sarolangun Tahun 2012 ( data diolah )

Dari tabel perhitungan proporsi efesiensi belanja daerah Kabupaten Sarolangun pada tabel 5.5 diatas dapat disimpulkan bahwa proporsi efesiensi belanja daerah Kabupaten Sarolangun selama tujuh tahun anggaran yaitu efesiensi dalam merealisasikan APBD yang telah ditargetkan karena selalu berada pada skala kurang dari $100 \%$ yang menurut skala perhitungan dalam Mahsun Moh (2006:186) menunjukkan kinerja efesiensi. Kabupaten Sarolangun berada pada kriteria efesiensi yang berada pada persentase kurang dari 100\%. Pada tahun 2006 sebesar 73,88\% menunjukkan kinerja yang efesiensi dalam merealisasikan anggaran yang telah ditargetkan. Pada tahun 2007 pemerintah mengalami kenaikan sebesar $78,17 \%$ menunjukkan kriteria efesiensi dalam merealisasikan APBD. Pada tahun 2008 pemerintah mengalami kenaikan dalam hal efesiensi anggaran belanja dapat dilihat dengan persentase dari perhitungan analisis rasio anggaran belanja sebesar 85,53\% dikategorikan efesiensi dalam merealisasikan APBD yang ditargetkan.

Selanjutnya pada tahun 2009 pemerintah mengalami kenaikan dalam hal efesiensi anggaran belanja hal ini dapat dilihat dengan meningkatnya persentase dari perhitungan analisis rasio anggaran belanja sebesar 94,90\%. Menunjukkan kinerja belanja daerah yang efisiensi dalam merealisasikan anggaran yang ditargetkan.Hal ini dikarenakan selisih antara anggaran dan realisasi belanja tidak jauh berbeda. Pada tahun 2010 pemerintah mengalami kenaikan dalam hal efesiensi anggaran belanja hal ini dapat dilihat dengan meningkatnya persentase dari perhitungan analisis rasio anggaran belanja 
sebesar 95,77\% dikategorikan efesiensi dalam merealisasikan APBD yang ditargetkan. Tahun 2011 pemerintah mengalami penurunan dalam hal efesiensi anggaran belanja sebesar Rp. 709.927.813.915,17 dengan meningkatnya persentase dari perhitungan analisis rasio efesiensi anggaran belanja sebesar 89,44\% menunjukkan kriteria efesiensi dalam merealisasikan anggaran yang ditargetkan.

Sedangkan tahun 2012 pemerintah mengalami penurunan dalam hal efesiensi anggaran belanja sebesar Rp. 816.611.263.104 hal ini dapat dilihat dengan meningkatnya persentase dari perhitungan analisis rasio efesiensi anggaran belanja yaitu sebesar 88,83\% menunjukkan kinerja yang efesiensi dalam merealisasikan anggaran yang ditargetkan. Hal ini dikarenakan karena selisih antara anggaran dan realisasi belanja tidak jauh berbeda. Kinerja pemerintah daerah dinilai baik apabila pemerintah daerah mampu melakukan efesiensi belanja daerah. Sebaliknya jika realisasi belanja lebih besar dari jumlah yang dianggarkan maka hal itu mengindikasikan adanya kinerja anggaran yang kurang baik.

\section{SIMPULAN DAN SARAN}

\section{Simpulan}

1. Penerimaan belanja daerah Kabupaten Sarolangun selama tahun 2006 - 2012 mengalami perkembangan rata - rata sebesar $20,67 \%$. Perkembangan negatif terjadi pada tahun 2010.

2. Kinerja belanja Kabupaten Sarolangun dilihat dari analisis pertumbuhan belanja Kabupaten Sarolangun menunjukkan bahwa pertumbuhan yang positif dengan rata rata 20,67\% dan pertumbuhannya cenderung fluktuatif. Rasio Keserasian Belanja kinerja Pemerintah Kabupaten Sarolangun berdasarkan Rasio Belanja Modal dan Belanja Operasional Pemerintah Kabupaten Sarolangun lebih mengalokasikan sebagian besar belanjanya untuk Belanja Operasional daripada Belanja Modalnya. Tingkat rata - rata efesiensi belanja Pemerintah Kabupaten Sarolangun selama tahun 2006 - 2012 sebesar 86,64\% yang tergolong efesien.

\section{Saran}

1. Pemerintah Kabupaten Sarolangun sebaiknya mengukur kinerja belanja secara kontinyu agar dapat mengontrol dan mengetahui kinerja belanja daerahnya dari tahun ke tahun agar tercapainya pengelolaan keuangan daerah yang baik, transparan, jujur dan akuntabel.

2. Pemerintah Kabupaten Sarolangun harus lebih baik dalam kinerja belanja supaya perkembangan belanja daerah Kabupaten Sarolangun kedepan selalu meningkat dan bersifat positif. Pada tingkat keserasian, rasio belanja operasional yang lebih besar daripada belanja modal harus dipertahankan dan di tingkatkan lagi untuk tahun selanjutnya. Pada tingkat efisiensi belanja yang sudah efesien harus dipertahankan setiap tahunnya.

\section{DAFTAR PUSTAKA}

Abdul Halim dan Theresia Damayanti, 2007. Seri Bunga Serampai Manajemen Keuangan Daerah. UPP-STIM YKPN, Yogyakarta.

Abdul Halim, 2008. Akuntansi Sektor Publik: Akuntansi Keuangan Daerah.Salemba Empat. Jakarta.

Ahmad Yani, 2008. Hubungan Keuangan antara Pemerintah Pusat dan Daerah di Indonesia. Raja Grapindo Persada. Jakarata. 
BAPEDA Kabupaten Sarolangun, 2011. RPJMD Kabupaten Sarolangun Tahun 20112016.

Depdagri, Permendagri Nomor 13 Tahun 2006 Tentang Pedoman Pengelolaan euangan Daerah. www.depdagri.go.id .online 1 Juli 2012.

DP2KAD, Kabupaten Sarolangun, 2011. Kemanpuan keuangan Daerah Kabupaten Sarolangun 2001-2010.

Kabupaten Sarolangun, 2011. Pertumbuhan belanja rutin dan belanja pembangunan Kabupaten Sarolangun 2001-2010.

Mahsun Moh, 2006 : 186. Kriteria Keserasian Belanja.

Permendagri Nomor 26 Tahun 2006 Tentang Pedoman Penyusunan APBD.www.depdagri.go.id . online 1 Juli 2012.

Peraturan Daerah Kabupaten Sarolangun Nomor 02 Tahun 2005 Tentang Pokok- Pokok Pengelolaan Keuangan Daerah dan Rancangan Pendapatan dan Belanja Daerah Kabupaten Sarolangun.www.depdagri.go.id . online 1 Juli 2012.

Peraturan Pemerintah Nomor 58 Tahun 2005 Tentang Pengelolaan Keuangan Daerah. www.depdagri.go.id . online 1 Juli 2012.

Haw.Widjaja, 2009. Otonomi Daerah dan Daerah Otonom. Raja Grapindo.

H.A Kartiwa 2004. "Proses penyusunan anggaran pendapatan dan belanja daerah (APBD) dan arah kebijakan umum"

Ridho Argi (2011) melakukan penelitian tentang "Analisis belanja daerah dan Faktorfaktor yang mempengaruhinya di kabupaten dan Kota Provinsi Jawa Tengah Periode 2004- 2009"

Siswanto Sunarno,2009. Hukum pemerintahan daerah di Indonesia. Sinar Grafita. Jakarta.

Undang-Undang Nomor 17 Tahun 2003 Tentang Keuangan Negara.

Undang-Undang Nomor 17 Tahun 2004 Tentang pengelolaan dan pertanggung jawaban atas pengelolaan keuangan pemerintah. www.depdagri.go.id . online 1 Juli 2012.

Undang-Undang Nomor 32 Tahun 2004 Tentang Pemerintahan Daerah.

Undang-Undang Nomor 33 Tahun 2004, Tentang Perimbangan Keuangan Daerah Antara Pemerintah Pusat dan Pemerintah Daerah. www.djlpe.esdm.go.id. Online 1 juli 2012.

www.depdagri.go.id . online 1 Juli 2012. 